Volume 18 Number 1 June 2018 .p.231-246

https://doi.org/10.30603/au.v18i1285

\title{
Democracy in Indonesia Towards Mangkunegaran: The Fade of Javanese Royal Palace's Political Power
}

\section{Sunarmi}

\author{
Indonesian Art Institute of Surakarta
}

\begin{abstract}
Mangkunegaran in early establishment initially had a capacity and authority armed with forces and territory, which currently only deemed as one of the cultural guardian institution even more physically interpreted as a cultural heritage object. The inability of Mangkunegaran to dampen the Anti-Swapraja Movement is actually the beginning for waning power politics in Mangkunegaran in the royal system with the doctrine of keagungbinataraan. Declarations to declaration issued by KGPAA Mangkunegara VIII to face the Anti Swapraja movement was compeletely ignored by the society. In traditional Javanese life, it is signed by oncate (the loss of) wahyu kedhaton of Mangkunegaran. In the end the Swapraja Region in Surakarta was revoked, Mangkunegaran has no authority as the center of government.
\end{abstract}

\begin{abstract}
Abstrak
Mangkunegaran di awal kekuasaannya memiliki kapasitas otoritas dengan angkatan bersenjata dan teritori, yang saat ini hanya dianggap sebagai salah satu lembaga cagar budaya yang secara fisik ditafsirkan sebagai objek warisan budaya. Ketidakmampuan Mangkunegaran untuk meredam Gerakan Anti Swapraja merupakan awal dari rontoknya politik kekuasaan di Mangkunegaran dalam sistem kerajaan dengan doktrin keagungbina-taraan. Strategi politik KGPAA Mangkunegara VIII dilakukan dengan mengeluarkan maklumat demi maklumat untuk menghadapi gerakan Anti Swapraja secara sepihak diabaikan oleh masyarakat. Dalam kehidupan tradisional Jawa, hal tersebut pertanda telah oncat (kehilangan) wahyu kedhaton Mangkunegaran, karena titah dalem sudah tidak mendapat perhatian. Akhirnya Daerah Swapraja di Surakarta dicabut, Mangkunegaran tidak memiliki kewenangan sebagai pusat pemerintahan.
\end{abstract}

Keywords: democracy; feudalism; power; Mangkunegaran; Javanese Royal Palace; Swapraja

Author correspondence

Email: sunarmi.interior67@gmail.com

Available online at http://journal.iaingorontalo.ac.id/index.php/au/index 


\section{A. Introduction}

Mangkunegaran is a former kadipaten 'duchy' in Surakarta which position departs from the splinter ruler to the ruler of kasunanan (on the Treaty of Salatiga 1757) which traditionally deemed pengageng has a lower-level position than the today's sunan found in the city of Surakarta. Due to secede from the Sunan's rulling (sultanate), the ruler's position of Mangkunegaran Palace is not a king, but only a Pangeran Merdeka, vrijeprins. Because the traditional position of the Mangkunegaran ruler is lower than that of the Sunan, it is not surprising for the Mangkunegaran ruler if he had to seek legitimacy of his existence through the symbol of foreign culture. The legitimacy, however, does not entirely abandon traditional Javanese features, but at least a pragmatic perspective and improved work ethic, as well as a high intellectual level will support the existence or image of the Mangkunegaran rulers who seem no more than the rank or position of the traditional Javanese ruler the so called Sunan. It is not surprising, therefore, that the influence of many European cultures emerges in the northern part of Surakarta where the Mangkunegaran's rulling lies ${ }^{1}$.

Mangkunegaran, which was originally a duchy, in current time does not have administrative territory. As the existence of other kingdoms in the archipelago, Mangkunegaran experienced a dilemmatic situation, especially its position and life existence in the system of the Indonsian Republic Government. Mangkunegaran which initially had a capacity as similar with a country armed with forces and territory, now only as one of the cultural guardian institution even more physically interpreted as a cultural heritage object. The Pengageng of Mangkunegaran has the duties as an elder to the relatives of Mangkunegaran, escorting the Kraton in its main task as a cultural axis. This means that, Mangkunegaran is obliged to maintain the existence and expression of the

\footnotetext{
${ }^{1}$ Sunarmi, Sudardi, Sukerta, Pitana, "The Fall of Mangkunegaran's Political, and Economic Authorities", Journal of Education and Social Sciences, Vol. 5, No. 2, October 2016: 181-186
} 
splendor of Javanese culture and all assets of Mangkunegaran including buildings co-exists in Pura Mangkunegaran².

The word political manifests two very important and synergistic elements, namely power and authority. In Javanese politics, although the executive, legislative, and judicial powers are distributed in an institution led by the court's 'courtiers' (abdi dalem), but the sole authority is in the hands of the king. Thus the ruler is more effective to implement public policy. Conversely, when power faces strong repression with the presence of counter-power, the government with the principles of comprehensive equality, known as democracy.

The issuance of the Republic of Indonesia's Law Number 11 Year 2010 On the Object of Culture, positioning the buildings of Pura Mangkunegaran as cultural heritage objects. In the Act, Chapter I of Article I verse 22 is explained, that cultural heritage objects should be preserved. Conservation is a dynamic effort to maintain the existence of a cultural heritage and its value by protecting, developing and utilizing it. Protecting is the effort to prevent and cope from damage, destruction, and annihilation. Developing is the act of enhancing potential value, information and promotion of cultural heritage while maintaining the authenticity and utilization through continuous research, revitalization and adaptation which goes hand in hand with the conservative goals. Utilization of cultural heritage must be undertaken to strengthen the positive image of regional development for the greatest benefit of people's wellfare.

Indonesian independence led to a fundamental change in the political and governmental order. As a newly established state, the sovereignty of the state lies in those who contribute to the formulation of the 1945 Constitution. Democratization gave rise to the existence of central and local governments. In this process there is sometimes pressure, violence and rebellion, especially in areas where government systems remain based on feudal traditions. Therefore, the struggle for independence is the realization of anti-colonialism and anti feudalism.

\footnotetext{
2 Sunarmi, Sudardi, Sukerta, Pitana, "Modernity Pressure Over Traditionalism In The Comodification Of Pracimayasa Building In Pura Mangkunegaran Surakarta", International Conference on Social Sciene, Arts, Economic and Education, Bangkok, 2016, pp.209-218
} 
Democracy means relying the government on the community, or at least the community is involved in making decisions about the main problems of government. Democratic governance can work in two ways: direct and indirect democrations. In modern countries, democratic governance is generally undertaken indirectly, through representative institutions representing people. For Mangkunegaran, giving authority to the community or democratization has an impact on a very significant change if it is viewed from the concept of authority in Javanese culture. Historically, the public has never really been involved in holding the authority to govern the governance, either in Mangkunegaran or Kasunanan. The rights of the people in the government are severely constrained by the great power of the king or pengageng. On the basis of such fact, it is quite interesting and important to know how the democratic process in Mangkunegaran ahead of Indonesian Independence.

This study is under the paradigmn of descriptive-qualitative approach along with using critical approach and semiotic theory. The data collection was done through the literature studies, observation, and in-depth interviews. At the time conducting field study, the author attempts to balance the information from various parties by selecting respondents from both the pros and cons on the discourse of "democracy and the existence of Pura Mangkunegaran's power after the independence of the Indonesian Republic Government".

\section{B. An Overview of Mangkunegaran Palace}

Pura Mangkunegaran of Surakarta is located in sub-district of Keprabon RT 20 , Banjarsari with a land area of $302.50 \times 308,2$. Based on such a fact, it is quite interesting and important to know how the process of democracy in Surakarta works. It is bordered by, on the south is Ronggowarsito road, western part is Kartini street, in the east is the Teuku Umar road, and north side is on the road R.M. Said. The main building of Pura Mangkunegaran is Pendapa Ageng which realized in joglo shaped, then Dalem Ageng is in joglo-shaped, Dalem Ageng is in 
pyramid shaped, and then the Peringgitan is in Kutuk Ngambang 3,4 . Pura Mangkuegaran is intentionally built to resemble a small palace in Surakarta which, although in essence each of them is not a palace.

Pura Mangkunegaran is the palace residence of Sri Paduka Mangkunegara ${ }^{5}$ in Surakarta and was built after 1757 by following a smaller palace model. Some of these buildings share the same characteristics with palace, namely; pendopo, pringgitan, dalem ageng, and kaputren, which are entirely surrounded by supporting buildings and sturdy walls. Keraton Mangkunegaran manifest the noble arts and culture 'adiluhung', priceless treasures and beautiful collections. Those cultural arts are deeply rooted from Majapahit kingdomhood (1293-1478) and Mataram (1586-1755) of the imperial period, classical mask dance (tari topeng), wayang orang (drama dance), leather puppets (wayang kulit), and wooden puppets, religious statues, jewelry and antiques and innumerable heirlooms ${ }^{6}$.

\section{Being Abolished as Swapraja District}

The development of Pura Mangkunegaran at present cannot be separated from the history of the Independence Proclamation of Indonesian Republic. It was realized early that the Nusantara government before the Independence of the Indonesian Republic embraced royal systems. At that time invaders came to Nusantara ship by ship and the Dutch were the longest occupiers in the Nusantara. Dissatisfaction of the people at the time marked by the grip of the invaders motivated rebellious movement in various areas became inevitable. Finally, Nusantara succesfully achieved the independence and set up a state so called Indonesia. The Independence of Indonesian Republic has been the concern of all Nusantaran people in a way to escape from the grip of invaders including the dream of establishing Mangkunegaran, the independence resulted a very significant impact on structural and cultural changes in Pura Mangkunegaran

\footnotetext{
${ }^{3}$ Rosalinda, H., \& Kholisya, "Memaknai Bentuk Rupa Lambang Keraton Mangkunegran”, Jurnal Desain, Volume 4, Nomer 2, Januari 2017, pp. 73-84

${ }^{4}$ Sunarmi, Sudardi, Sukerta, Pitana, "Comodifacion of Pracimayasa Building In PuraMangkunegaran Surakarta", Proceding International Conference: International Indonesian Forum for Asia Studies (IFFAS), 2016.

${ }^{5}$ The name of Sri Paduka is a name of currently accustomed in Pura Mangkunegaran.

${ }^{6}$ Wasino, Modernisasi Di Jantung Budaya Jawa: Mangkunegaran, 1896-1944 (Jakarta: Penerbit Buku Kompas, 2014), 16.
} 
which was then called a kadipaden or duchy. It could be said that since the Proclamation of Indonesian Independence was the beginning of the collapse on the system of the governmental Kingdom in Pura Mangkuegaran.

Dissatisfaction with the existence of Colonial in the archipelago encouraged the emergence of support from various regions of the kingdom and duchy with authority and legitimacy of locality that originally existed in the system of government of the kingdom, then began to move its movement on the establishment of the Unitary State. The peak of the movement was proclaimed Independence of the Republic of Indonesia on August 17, 1945. The four leaders in Central Java are KGPAA Mangkunegara VIII from Mangkunegaran, Pakubuwana XII from Kasunanan Surakarta, Sultan Hamengkubuwana IX from Yogyakarta Sultanate, and Adipati Paku Alam VIII from Paku Alaman Yogyakarta fully expressed their support for the establishment of the Unitary State of the Republic of Indonesia in early September 1945.

Post-proclamation of Indonesian Independence, began to set up State Institutions in charge of taking care of government problems. At the session of PPKI (Panitia Persiapan Kemerdekaan Indonesia) 'Preparatory Committee for Indonesian Independence' or Dokuritsu junbi Inkai dated August 18, 1945 stipulated the division of powers and administrative in the territory of the Indonesian Republic, Swapraja government was legally recognized as part of the sovereignty of the Republic of Indonesia. The recognition is contained in Article 18 of the 1945 Constitution "concerning central and regional relations, including in the region of Swapraja". De facto and de jure, the Duke of Mangkunegara VIII in Mangkunegaran at the time of Indonesian independence, is absolute and autonomous Swapraja form. At that time Mangkunegaran was led by Kanjeng Gusti Pangeran Adipati Arya (KGPAA) Mangkunegara VIII (Presidential Charter of Indonesian Republic on August 19, 1945, Rekso Pustoko Mangkunegaran Archive No. 7822.

The emergence of anti-Swapraja movement in Surakarta, Mangkungera VIII, that Mangkunegaran is facing a crisis of legitimacy. To confront the various 
legitimacy crises primarily derived from the Anti-Swapraja group in Surakarta, KGPAA Mangkunegara VIII issued A Declaration dated September 1, 1945 which contains the following. (1) The Kingdom of Mangkunegaran is a Special Region of the Sovereign State of the Indonesian Republic. (2) All government affairs in Mangkunegaran shall then be established and governed by the Mangkunegaran government itself, in view of the regulations of the Indonesian Republic Government. (3) The relationship between Mangkunegaran and the Indonesian Republic government is direct (Declaration of KGPAA Mangkunegoro VIII, September 1, 1945, Archive of Mangkunegaran No. 2420. 3).

The position of Mangkunegaran to manage the Swapraja region in Surakarta was acknowledged by the State of Indonesian Republic is affirmed in the decision of Pengageng Mangkunegaran through the declaration as the article of the 1945 Constitution Article 18 on the relationship between the Central and Regional Governments, including the region of Swapraja. Sharing similarity with ruler of the Regional Government who issued a Decree on Position and Government System fully realized as a part of the State of Indonesian Republic within the framework of a special area, Mangkunegaran bear itself a fact that it has position under the State of RI. On the other hand also refers to the Charter of Status issued by the President of the Indonesian Republic on 19 August 1945.

However, the efforts undertaken by Mangkunegara VIII by issuing the Declaration was ignored by the Anti-Swapraja Movement. The desire of the antiSwapraja Movement to abolish the Swapraja Region in Surakarta continuely fought. Ongoing intimidation in Surakarta from the Anti-Swapraja movement. Meanwhile, the government did not show any action to support Mangkunegaran in reducing the movement. Swapraja was highly resisted and did not get any meaningful support in Surakarta. Swapraja ws only the desire of a small group of Surakata people who support the existence of Kasunanan and Mangkunegaran which at that time really as a minority. Mangkunegaran power seemed to have vanished as the center of government. This can be seen, on the evidence of the inability to control chaos in Surakarta. The authority of a Pengageng in the eyes of the people as if it had been declared and proved that all the information had not 
received attention, physical strength of the valiant legend of Mangkunegaran was once able to conquer the Colonials, when it was unable to take part in securing the Swapraja.

Under such conditions, the RI (Republic of Indonesia) government issued a declaration on May 23rd, 1946, containing that the Government of Indonesian Republic would temporarily place a representative in Surakarta. The government action that would place a representative in Surakarta shows that the government itself does not wholeheartedly support the existence of the Swapraja Region in Surakarta. This can be seen when the conflict caused by anti-Swaparja movement, Kasunanan and Mangkunegaran had to fight their own to muffle those rebellious actions. In that situation, the Government of Indonesia has not been stable yet, but NKRI has been established which means that all matters of regional government are of course also a problem of RI government, when local government unable to control, consequently things expected from local government was the aid from the central government. However, the Mangkunegaran hoped that the Government of RI has placed a representative in Surakarta. Actions undetaken by the RI government differently interpreted by the Anti-Swapraja Movement, that it was the support of the Anti-Swapraja Movement, thus it did strengthening them. For Mangkunegaran itself, the deployment of Indonesian envoys in Surakarta was interpreted as a threat to the continuity of the Swaparja Region in Surakarta, thus it reaffirmed the position of Mangkunegaran in Surakarta.

\section{Javanese Political Culture}

Political experts and academics use the terminology of political culture to understand the political systems and processes in a particular social society. This terminology is generally used to understand political units on a national scale as an expression of the national character reflected in the political structure and governance of the king as God's reincarnation is changed to kalifatullah, God's representative on earth, especially at the time Islam took over kingdoms in Java Island for the essential teachings of Islam did not justify the equalization of man 
with God7,8 . However, this Islamic influence did not diminish the absolutism of a king to kalifatullah, for essentially he has no faults nor errors and thus his words and commands are from God 9.

The Javanese political concept of the center has implications for the conception of sovereignty, territorial integrity, and international relations. For the people of Java, the state is defined not by its borders but its center. This means that, for the Javanese people, control over the population is more important than control of the territory. Therefore, the abundant population concentration around a leader is a sign that he is in fact both the center of power and the universe $\mathbf{1 0}$. Therefore, "when a king claimedcontrol over a particular expanse of territory, infact what he claimed was the control of the labor ofthe land's residents and a portion of the product of their labor"11.

\section{The Transformation of Javanese Power}

ithout intending to simplify, Javanese political and cultural entities were present long before Indonesia was proclaimed. Of course, Javanese culture is more established than the concept of Indonesian democracy that emerged later. The concept of royal power came to adapted throughout archipelago as Hinduism influences. Especially in Java, it was developed the concept of Javaism power 12. The rules were then institutionalized by the Mataram Kingdom, the area then transformed into several political entities with its main axis in Mangkunegaran. Thus, reviewing the Surakarta political system especially in Pura Mangkunegaran can not be separated from the concept of Javaism power.

\footnotetext{
${ }^{7}$ Emmerson, R.M., Social Exchange Theory, Annual Review of Sociology, Volume 2, 1976

${ }^{8}$ Khoirul Umam, A. \& Junaidi Arif, A. "The Shadow of Islamic Ortodoxy and Syncretism in Contemporary Indonesian". Al-Ulum Journal of IAIN Sultan Amai Gorontalo, Vol. 11, No. 2, 2011

9 Try Yuniyanto, Daulat Raja Menuju Daulat Rakyat-Demokratisasi Pemerintahan Di Yogyakarta (Solo: Cakrabooks, 2010).

10 Benedict Anderson, Language and Power-Exploring Political Culture in Indonesia (New York: Cornell University Press, 1991).

${ }^{11}$ Nancy Lee Peluso, Poor People: Resource Control and Resistance in Java (California: University of California Press, 1994), 34.

12 G Moedjanto, Konsep Kekuasaan Jawa: Penerapannya Oleh Raja-Raja Mataram (Yogyakarta: Kanisius, 1987), 121.
} 
A number of traditional historiography such as Babad Tanah Djawi (BTD) and Serat Centhini illustrate the absolute power of a king in Javanese society. In the BTD for example, it says, "Everything that is in the land of Java, the earth where we live, the water we drink, the grass, and the leaves and everything on the earth, belongs to the king." ${ }^{13}$. The collection of power in one hand based on this political interest will preserve the ideology of monarchic absolutism ${ }^{14}$. Moreover, the king was also comparable to a concept warana ning Allah or the representative or incarnate of God. The king is the absolute holder of all state power.

The illustration of the king as the absolute ruler is also reflected in Serat Centhini which states that the king is the true mastermind who has the right to govern life by receiving the mandate from God. The true master is the king of kings (God), while the king is the successor of the prophet, the prophet is the successor of the Supreme Being, therefore the kings of the Apostles are the Visible God (Serat Centhini, VII, 1932 in Moedjanto ${ }^{15}$. The Javanese believed that only the middlies were the only intermediaries that connected the human microcosm with the macrocosm of the gods. Moertono mentions, the idea of absolute and supreme power is expressed in the expression of authority murba wisesa which means the omnipotence of God and the power of the king. Again this confirms that the king is a reflection of God's position.

The concept of absolutism at the hand of the king's power is reinforced by the doctrine of the land greatness. This doctrine is attached to the puppet plays depicting great power as gung binathara, bau dhendha nyakrawati which means as much as the power of god, the keeper of the law, and the ruler of the ${ }^{16}$. By this doctrine, the king as the ruler of the state is entitled to take any action and in any way to his kingdom, including all that is in it, both natural resources and human resources. Here, the Mataram kings play the role of lawmakers, law enforcers, and judges alike. It was as if the king was completely untouched by the average person.

\footnotetext{
13 Moedjanto, 121.

14 Soemarsaid Moertono, Negara Dan Usaha Bina-Negara Di Jawa Masa Lampau: Studi Tentang

Masa Mataram II Abad XVI Sampai XIX. (Jakarta: Yayasan Obor Indonesia, 1985), 42.

15 Moedjanto, Konsep Kekuasaan Jawa: Penerapannya Oleh Raja-Raja Mataram, 122.

16 Moedjanto, 77-78.
} 
The idealization of king as ruler of a kingdom is certainly quite contrast to be compared with the concept of democracy that developed later. This comparability becomes very much interesting if it is associated with the contemporary reality of Surakarta society. The upheaval of cultural identity and modernization exhaled by the colonial government created a condition of transitional society in Indonesia. And, one of those transitional moments is the Revolution of Independence. The Whirlpool of the Independence Revolution directly or indirectly brought Mangkunegaran to such rapid changes. The monarchy of the monarchy transformed into a democratic society with its principal instrument of first-choice elections in 1951. The concept of transformation is in line with Bhaskar's definition in Agus Salim 17. which emphasizes that in social change, reproduction and transformation are always happening.

In the traditional life of Javanese society, it can be said when chaos or gonjang ganjing occured at Swapraja area ends at oncate (the lost of) wahyu kedhaton from Mangkunegaran. The pre-Islamic Javanese period, the crowned king and the royal leader is someone who is believed to have a royal ritual wahyu keraton which is the so-called wahyu kedhaton or wahyu cakraningrat ${ }^{18}$. This revelation is a prime requirement for a King in Java whose legitimacy should be reinforced by the concept of queen binathara. According to Soeratman, to become a king he who should have special quality of gung binathara a king must complete it with the following three revelations.

a. Wahyu nabuah is wahyu which occupied the king as the representative of the Absolute Power.

b. Wahyu kukumah, is a wahyu that places the King as a source of law with authority murbawasesa, means to master and act violently. His position as Sang Murbawasesa this resulted in the king having unlimited power and all his decisions should not be challenged, because it is considered as God's will.

\footnotetext{
${ }^{17}$ Agus Salim, Perubahan Sosial: Sketsa Teori Dan Refleksi Metodologi Kasus Indonesia (Yogyakarta: Tiara Wacana, 2002), 120.

${ }^{18}$ Purwadi, Sejarah Sultan Agung: harmoni antara agama dengan negara (Media Abadi, 2004), 2.
} 
c. Wahyu wilayah, is a wahyu completing the wahyu nubuah and kukumah, meaning the king is the source of enlightenment and protection to his people ${ }^{19}$.

On the event of gonjang ganjing Swapraja Region in Surakata, KGPAA Mangkunegara VIII proved unable to be the ratu gung binathara. This can be seen at the declaration of KGPAA Mangkunegara VIII dated September 1, 1945 as titah dalem has not been heard by all the people, although with the edict there are still a group of people who declare for their loyalty to Mangkunegaran (see the decision of Mangkunegaran employee meeting on Tuesday October 16, 1945) which can thus be said at that time there are already signs 'wahyu nubuah 'that the king's authority has faded. Until the end of March 20, 1946, KGPAA Mangkunegara VIII which contained threats would take decisive actions against the group that made the chaos not heard by the people, even the more intense resistance of the AntiSwapraja Movement carried out kidnappings and intimidation. This shows that raja sing kanggonan wahyu sang murbawasesa (The rightful king has a revelation Sang Purbawasesa) has lost its power, so it can be said as a sign Wahyu kukumah KGPAA Mangkunegara VIII is absolutely oncat (went away).

The incident was basically the beginning of Javanese society's understanding against the existence of Mangkunegaran in the era of independence was no longer the place of the ruling king. The anti-Swapraja movement sees to make Mangkunegaran a Swapraja region means to make the King and Duke share the power of politics and territory, also to revive the spirit of feudalism which is no longer appropriate with the spirit of the development of the nation and state. Feudalism must end to Indonesia nation and state.

\section{E. Kawula-Gusti versus People's Sovereignty: Portrait of Social Change}

After the Independence of the Indonesian Republic in 1945, there was a change of the royal government system into the system of government of Indonesia. The state (the government) entered a period that carries out

\footnotetext{
${ }^{19}$ Purwadi, 3-4.
} 
modernization within the framework of development. Mangkunegaran as a part of Indonesian citizen must participate in following the prevailing laws and regulations. Governance systems has to evolve in the spirit of better life improvements leading to efficiency and effectiveness.

Studying true power does not escape from the dominated object: the people. In the perspective of social change, the comparisons of Surakarta before and after independence provides a complete picture on the change of a society. However the change of absolute power into a democratic one shows such a contrasting picture in the historical episode. One such contrast is the shift of the feudal society into a democratic society. That is, a society with almost no power becomes a major entity in the life of the state.

Why contrast? The answer can be traced from the concept of absolute Javanese power. In the concept of Javanese power, the relation of the kings is reflected in the concept of kawula-gusti. Both are essential elements in the survival of an organization: governing and regulating; leaders and followers ${ }^{20}$. This pattern is unique because it is not merely a formal tie between the ruler and the people, but develops a personal bond, mutual respect, and responsibility.

In Javanese mysticism, the phrase jumbuhing kawula gusti which means unity of servant and master depicts the highest goal in human life. Moertono notes this frame of picture a dramatic depiction because the words kawula and gusti show the lowest human status on one side and the highest in society on the other. This cultural gulf is increasingly institutionalized with the use of different Javanese languages, especially the development of the ngoko-krama ${ }^{21}$. Other instruments are the procedures for the use of clothing and the way of reverence 22 .

The above description of Javanese society contrasts with the democratic laws that provide and direct the sovereignty of the people. Representation of public good is the general election to place the representatives of the people in

\footnotetext{
${ }^{20}$ Moertono, Negara Dan Usaha Bina-Negara Di Jawa Masa Lampau: Studi Tentang Masa Mataram II Abad XVI Sampai XIX., 17-19.

${ }^{21}$ Moedjanto, Konsep Kekuasaan Jawa: Penerapannya Oleh Raja-Raja Mataram, 42.

22 Moertono, Negara Dan Usaha Bina-Negara Di Jawa Masa Lampau: Studi Tentang Masa Mataram II Abad XVI Sampai XIX., 19.
} 
representative institutions. In the beginning, of course, this has become something new in Surakarta society. The common people who originally were the subjects without power suddenly got the right to convey their political aspirations. The submission of political aspirations is marked by a vote to elect members of the Regional People's Legislative Assembly (Dewan Perwakilan Rakyat Daerah, DPRD).

\section{F. Conclusion}

The inability of Mangkunegaran to dampen the Anti-Swapraja Movement is actually the beginning for waning power politics in Mangkunegaran in the royal system with the doctrine of keagungbinataraan. This concept is a legacy of Javanese society pre-Islamic period, the king who was crowned and led the kingdom is someone who is believed to get the wahyu keraton 'royal ritual' the so called wahyu kedhaton or wahyu cakraningrat. Wahyu kedhaton or wahyu cakraningrat will be a quality to a person when he is a king having wahyu nabuah, kukumah, wilayah characterized by the ability to defend the territory and compliance of the people on sabda pandita ratu or dhawuh dalem. Declarations to declaration issued by KGPAA Mangkunegara VIII to face the Anti Swapraja movement was completely ignored by society. In traditional Javanese life, as a sign of oncate (loss) wahyu kedhaton of Mangkunegaran. In the end the Swapraja Region in Surakarta was revoked, Mangkunegaran has no authority as the center of government.

The condition has a significant influence on social change in Surakarta. In the perspective of social change, the comparisons of Surakarta before and after independence provide a complete picture of the social change. The change of absolute power to democracy shows a contrasting picture in the historical episode, ie the shift of the feudal society into a democratic society. A society with almost no power becomes a major entity in the life of the state. In the Javanese mystic, the expression jumbuhing kawula gusti which means the union of servant and master depicts the highest goal in human life. This phrase is so dramatic because the words kawula and gusti show the lowest human status on one side and the highest in society. This cultural gulf is increasingly institutionalized through the use of Javanese, dress codes, and reverence. Meanwhile, in the concept of the Unitary 
State of the Republic of Indonesia, with democratic laws that direct sovereignty to the people. The voice of the people has the highest authority. Representation of the good fortune of the people is an election to place the representatives of the people in a representative body called Dewan Perwakilan Rakyat Daerah (DPRD) 'the Regional Representative'. 


\section{REFERENCES}

Anderson, Benedict. Language and Power-Exploring Political Culture in Indonesia. New York: Cornell University Press, 1991.

Emmerson, R.M., "Social Exchange Theory", Annual Review of Sociology, Vol. 2, 1976

Khoirul Umam, A. \& Junaidi Arif, A. "The Shadow of Islamic Ortodoxy and Syncretism in Contemporary Indonesian". Al-Ulum Journal of IAIN Sultan Amai Gorontalo, Vol. 11, No. 2, 2011.

Moedjanto, G. Konsep Kekuasaan Jawa: Penerapannya Oleh Raja-Raja Mataram. Yogyakarta: Kanisius, 1987.

Moertono, Soemarsaid. Negara Dan Usaha Bina-Negara Di Jawa Masa Lampau: Studi Tentang Masa Mataram II Abad XVI Sampai XIX. Jakarta: Yayasan Obor Indonesia, 1985.

Peluso, Nancy Lee. Poor People: Resource Control and Resistance in Java. California: University of California Press, 1994.

Purwadi. Sejarah Sultan Agung: harmoni antara agama dengan negara. Media Abadi, 2004.

Rosalinda, H., \& Kholisya, "Memaknai Bentuk Rupa Lambang Keraton Mangkunegran”, Jurnal Desain, Vol. 4, No. 2, Januari 2017: 73-84

Salim, Agus. Perubahan Sosial: Sketsa Teori Dan Refleksi Metodologi Kasus Indonesia. Yogyakarta: Tiara Wacana, 2002.

Sunarmi, Sudardi, B., Sukerta, P.M., Pitana, T.S. "The Fall of Mangkunegaran's Political, and Economic Authorities", Journal of Education and Social Sciences, Vol. 5, No. 2, October 2016: 181-186

Sunarmi, Sudardi, Sukerta, Pitana, "Modernity Pressure Over Traditionalism In The Comodification of Pracimayasa Building In Pura Mangkunegaran Surakarta", International Conference on Social Sciene, Arts, Economic and Education, Bangkok, 2016, pp.209-218

Sunarmi, Sudardi, Sukerta, Pitana, "Comodifacion of Pracimayasa Building In PuraMangkunegaran Surakarta", Proceding International Conference :International Indonesian Forum for Asia Studies (IFFAS), 2016.

Wasino. Modernisasi Di Jantung Budaya Jawa: Mangkunegaran, 1896-1944. Jakarta: Penerbit Buku Kompas, 2014.

Yuniyanto, Try. Daulat Raja Menuju Daulat Rakyat-Demokratisasi Pemerintahan Di Yogyakarta. Solo: Cakrabooks, 2010. 